\title{
Management of Snap Bean Insect Pests and Diseases by Use of Antagonistic Fungi and Plant Extracts
}

\author{
J. W. Muthomi ${ }^{1}$, A. M. Fulano ${ }^{1}$, J. M. Wagacha ${ }^{2}$, \& A. W. Mwang'ombe ${ }^{1}$ \\ ${ }^{1}$ Department of Plant Science and Crop Protection, University of Nairobi, Kenya \\ ${ }^{2}$ School of Biological Sciences, University of Nairobi, P. O. Box 30197, 0100 GPO, Nairobi, Kenya \\ Correspondence: Department of Plant Science and Crop Protection, University of Nairobi, Kenya. E-mail: \\ james_wanjohi@yahoo.com; james.muthomi@uonbi.ac.ke
}

Received: March 22, 2017 Accepted: May 19, 2017 Online Published: June 17, 2017

doi:10.5539/sar.v6n3p52 URL: https://doi.org/10.5539/sar.v6n3p52

\begin{abstract}
Use of synthetic pesticides reduces the competitiveness of Kenyan snap bean pods due to stringent regulations by importers as a result of presence of chemical residues. This study was conducted to determine the effectiveness of local biopesticides in managing insect pests and diseases of snap beans. Field experiments were set up in farmer's field where Trichoderma spp. and Paecilomyce spp. and plant extracts from turmeric, garlic, ginger and lemon were applied weekly as foliar sprays. Plant extracts reduced the population of whiteflies and thrips by up to $58 \%$ and $41 \%$ while antagonistic fungi had a corresponding $30 \%$ and $18 \%$ reduction, respectively. Trichoderma spp. reduced severity of angular leaf spot $(37.5 \%)$, rust $(67 \%)$ and anthracnose $(20.7 \%)$. Plant extracts and antagonistic fungi increased marketable pod yield by $25.6 \%$ and $17.3 \%$, respectively. Results demonstrated that local environments are potential sources of biopesticides that can be exploited for integrated management of pests and diseases.
\end{abstract}

Keywords: Biopesticides, botanical pesticides, microbial pesticides, maximum residue limits, snap beans, sustainable agriculture

\section{Introduction}

Kenya is reputed in producing the world's finest snap beans (Ndung'u, 2013) which account for about $60 \%$ of all vegetable exports and $21 \%$ of all horticultural exports (HCDA, 2011). Snap bean is ranked first among the export horticultural crops in Kenya that earns foreign exchange (USAID-KHCP, 2015). This highly valued vegetable generates income to smallholder farmers and creates employment hence improving household livelihoods (Odero et al., 2013; Wahome et al., 2013). The greatest threat to snap bean production is insect pests and diseases which cause economic losses. Conventional pest and disease control methods which rely mainly on synthetic pesticides have failed in meeting the premium quality of pods desired by niche European markets (Wahome et al., 2013) due to accumulation of chemical residues in fresh produce, health risks to growers, development of resistance to pesticides by the target pests and environmental pollution (Aktar et al., 2009; Kimani, 2014; Soliman et al., 2015).The European Union has set the maximum residue limit (MRL) at $0.01 \mathrm{mg} / \mathrm{kg}$ (European Commission, 2012). The strict maximum residue level (MRLs) requirements could result in loss of trade because small holder snap bean growers may stop production due to fear of non-compliances, high costs and delays in clearing of consignments (KEPHIS, 2012). The stringent pesticide regulations resulted in a $25 \%$ reduction in snap bean sales in 2013 compared to 2012. Therefore, if vegetable farmers are to access the niche EU and local supermarket markets, there is need to search for alternative pest management approaches that are user friendly, that leave no harmful chemical residues on the product and safe to environment.

The negative effects of using synthetic pesticides in agricultural production has stimulated continued search for alternative pest control approaches (Nderitu et al., 2009). The most commonly used biological pesticides include microbial antagonists, bio-insecticides, botanical pesticides and compost teas (Nega, 2014; Quarles, 2013). Microbial antagonists used to control plant diseases include Trichoderma harzianum, Gliocladium virens, Coniothyrium minitans, Agrobacterium radiobacter, Bacillus subtilis, Pseudomonas spp. and Streptomyces spp. while botanical pesticides include pyrethrum, neem, rotenone, rape seed oil, quassia extract, neem oil and nicotine (Nega, 2014; Quarles, 2013). Insecticidal biopesticides include Beauveria bassiana, Metarhizium anisopliae, Paecilomyces spp. and Verticillium lecanii. Botanical pesticides such as pyrethroids and neem are as 
effective as the synthetic chemicals in reducing pest damage (Nega, 2014). The use of biopesticides such as microbial antagonists and botanical pesticides in management of pests and diseases in snap bean production offers an appropriate alternative to synthetic pesticides because they are highly efficacious, are relatively cheaper, safer to use and leave no toxic residues (Quarles, 2013; Koul, 2011; Krishan, 2014; Ouma et al., 2014). Biopesticides are relatively safe and acceptable to consumers (Gurjar et al., 2012). Microbial pesticides can multiply on or in vicinity of the target pest thus giving self-perpetuating control (Chandler et al., 2011) and have plant growth promoting effect that trigger induced systemic resistance in plants (Islam et al., 2012). Plant growth promoting rhizobacteria and other microbial antagonists widely occur in soils and rhizosphere (Kumar et al., 2011). Compared to synthetic pesticides, biopesticides are less harmful to non-target organisms, are often effective in small quantities, decompose quickly and therefore have less residual effects (Gupta and Dikshit, 2010). They have been found to be effective and sustainable in management of pests and diseases in vegetable production (Killani et al., 2011; Srinivasan, 2012).

Trichoderma spp. produce diffusible and volatile antibiotics plus hydrolytic enzymes which are the crucial mechanisms behind their biocontrol activity (Navaneetha et al., 2015). Paecilomyces as entomopathogenic fungi is reported to suppress several insects as a foliar spray though with varying efficacies (Archana and Ramaswamy, 2012). Plant extracts are reputed to constitute various bioactive compounds and secondary metabolites such as alkaloids, flavonoids and phenolic compounds. These substances possess synergistic effects on retarding growth of pests and suppression of pathogens hence act as insecticidal and antifungal agents (Ahmed et al., 2012). Plant extracts have been successfully applied against insect pests and diseases (Shahid et al., 2015). In Kenya formulated products of neem and pyrethrum are currently used whereas a mixture of garlic and pepper has been recommended to manage insect pests (Infonet-Biovision, 2015; Ogala, 2013). In a study by Waiganjo et al., (2011), neem oil extracts, Achook ${ }^{\circledR}$ and Nimbecidine ${ }^{\circledR}$ suppressed the population of aphids and diamondback moth in cabbage. Extractsfrom garlic bulb contain allicin (Wei et al., 2011) while the rhizome of turmeric contain curcuminiods (60\% curcumin) all responsible for insecticidal and antimicrobial properties (Ahmed et al., 2013). The current study investigated the effectiveness of local antagonistic microorganisms and crude plant extracts against major pests and diseases of snap bean as alternatives to synthetic pesticides for reduced chemical residues in the produce destined for niche markets.

\section{Materials and Methods}

\subsection{Experimental Materials}

The fungal antagonists evaluated were Trichoderma viride, T. harzianum, T. asperellum and Paecilomyces while crude plant extracts were turmeric, garlic, ginger and lemon. The fungal antagonists were multiplied on sterile sorghum. Five mycelial agar plugs (10mm diameter) of each of the four antagonistic fungi were inoculated in polythene sleeves with cooled autoclaved sorghum under sterile conditions. The contents were then shaken well to evenly disperse the inocula before incubation at room temperature $\left(23 \pm 2{ }^{\circ} \mathrm{C}\right)$ for 14 days. During the incubation, the contents of the polythene sleeves were shaken once after two days to prevent aggregation. Standardization of conidia in suspension was carried out in the laboratory before prior to field application. Conidia of each fungal antagonist were harvested by flooding the substrate having fungal growth with sterile distilled water then filtered through two layers of cheesecloth to obtain conidia suspension. The number of conidia in suspension in which had $0.05 \%$ Tween $20^{\circledR}$ (polyoxyethylene sorbitol esters) added was standardized to $1 \times 10^{8}$ conidia $\mathrm{ml}^{-1}$ for each fungal antagonist. The polythene sleeves with selected antagonistic inoculant growing on sorghum for 14 days were carried to the field. The conidia suspension for each antagonist was prepared in the same way as during standardization. Fresh turmeric rhizome, garlic corm, ginger rhizome and lemon fruit each weighing $100 \mathrm{~g}$ were finely blended and extracted with $95 \%$ ethanol. The ethanol extracts was concentrated by vacuum evaporation and $10 \mathrm{ml}$ of each crude plant extract was transferred to the universal bottle. Ten $\mathrm{ml}$ of each of the extract was added into five litres of water having one drop of $0.05 \%$ Tween $20^{\circledR}$.

\subsection{Experimental Design and Layout}

On-farm experiments were conducted in Mwea in Kirinyaga County, Kenya. The average rainfall in Mwea is about $850 \mathrm{~mm}$ with a range of 500-1250 $\mathrm{mm}$ per annum divided into long rains and short rains. The annual mean temperature ranges from $15.6^{\circ} \mathrm{C}$ to $28.6^{\circ} \mathrm{C}$ which meets the ecological requirements for snap bean production (Kamanu et al., 2012). The field was divided into plots measuring $3 \mathrm{~m}$ by $3 \mathrm{~m}$ with $1 \mathrm{~m}$ alleys between the plots and $1 \mathrm{~m}$ alleys between the blocks. The variety of snap beans mostly grown by farmers was planted in single rows with spacing of $15 \mathrm{~cm} \times 30 \mathrm{~cm}$ in each plot. Di-ammonium phosphate (DAP) at a rate of $200 \mathrm{~kg} / \mathrm{ha}$ was mixed well with soil before placement of seeds. First weeding was carried out two weeks after emergence (WAE) while second weeding was at fifth WAE. The plants were side dressed with Calcium ammonium nitrate (CAN) at 
a rate of $100 \mathrm{~kg} / \mathrm{ha}$ at flowering stage. Furrow irrigation was done to field capacity twice per week in absence of rain. The antagonistic fungi and plant extracts were applied weekly as a foliar spray, commencing one week after emergence until pod setting. Each antagonistic fungus was applied at a concentration of $1 \times 10^{8}$ conidia ml-1 while each of the extract was at $10 \mathrm{ml}$ in 5 litres of water having one drop of $0.05 \%$ Tween $20^{\circledR}$. The efficacy was compared to that of synthetic pesticides Dithane $\mathrm{M}-45^{\circledR}$ and Confidor $70 \mathrm{WG}^{\circledR}$ that were alternately applied and commercial formulations of Trichoderma $\left(\right.$ Trianum $\left.^{\circledR}\right)$ and neem $\left(\right.$ Achook $\left.^{\circledR}\right)$. Commercial neem, Achook ${ }^{\circledR}$ was applied at a rate of $20 \mathrm{ml}$ in 20 Litres of water. Commercial Trichoderma (Trianum ${ }^{\circledR}$ ) was applied at a rate of $5 \mathrm{~g}$ in 5 litres of water having a concentration of $1 \times 10^{8}$ spores $/ \mathrm{ml}$. However, synthetic fungicide, Dithane M- $45 \circledR$ (Mancozeb $80 \% \mathrm{~m} / \mathrm{m}$ ) was applied at a rate of $50 \mathrm{gm}$ in 20 Litres of water. Control plots were sprayed with water The treatments were replicated three times and the experiment was laid out in a randomized complete block design (RCBD).

\subsection{Assessment of Pest Infestation}

The population of whiteflies was determined by counting the number of nymphs on lower surface of 10 leaves from ten plants through non-destructive sampling. The 10 plants were tagged in a zigzag manner from inner rows of each plot (Wafula, 2014). This was carried out five times at third, fourth, fifth, sixth and seventh week after emergence (WAE). The population of thrips was assessed through destructive sampling of one flower from ten tagged plants per plot at random from the inner rows. The harvested flowers were kept in $70 \%$ ethanol and were taken to the laboratory to determine the population. Each flower was placed in a Petri dish, dissected and washed with water making sure that no thrips was lost with the debris (Nderitu, et al., 2009). Thrips were counted using dissecting microscope and a tally counter (Wafula, 2014). Assessment of population of thrips was carried out three times fifth, sixth and seventhweeks after emergence.

\subsection{Determination of Disease Index}

Evaluation was done on the distribution, incidence and severity of angular leaf spot, rust and anthracnose from second to seven WAE. Distribution of disease was done by observing how each disease was spread in the whole field using a 0-2 distribution scale; where $0=$ no disease, $1=$ spots, $2=$ whole plot. Assessment of incidence of disease involved counting diseased plants that showed symptoms of each disease and the percentage of disease incidence calculated according to the formula by Wheeler (1969):

$$
\text { Percentage disease incidence }=\left[\frac{\text { number of infected plants }}{\text { total number of plants }}\right] 100
$$

Assessment of severity was based on a scale of 0-5 (Stavely, 1985); where $0=$ no disease, $1=<20 \%, 2=$ $21-40 \%, 3=41-60 \%, 4=61-80 \%, 5=81-100 \%$ leaf area infected. Ten plants were randomly sampled and tagged from three inner rows in each plot by scoring three trifoliate leaves sampled at bottom, middle and top of each plant (Wahome et al., 2011). Total disease indices were computed using scores of distribution, incidence and severity. Percentage disease index was computed using the formula modified from McKinney (1923):

$$
\text { Disease index }(\%)=\frac{\text { distribution score }+ \text { incidence score }+ \text { severity score }}{\text { maximum distribution score }+ \text { maximum incidence }+ \text { maximum severity score }} \times 100
$$

Area under disease progress curve (AUDPC) was computed from the mean severity scores of data recorded at each assessment day (seven days interval) as described by Shaner and Finney (1977):

$$
\operatorname{AUDPC}=\sum_{i=1}^{n-1}\left[\left(Y_{i+1}+Y_{i}\right) / 2\right]\left(X_{i+1}-X_{i}\right)
$$

where, $Y^{\mathrm{i}}=$ disease severity at $\mathrm{i}^{\text {th }}$ assessment, $\mathrm{X}^{\mathrm{i}}=$ number of days after inoculation at the $\mathrm{i}^{\text {th }}$ assessment and $\mathrm{n}=$ total number of assessments.

\subsection{Assessment of Yield and Yield Components}

Harvesting of fresh pods was done once a week for three weeks in whole plots. Fresh pods harvested per plot were graded into two major categories namely marketable and non- marketable. The category of marketable was graded into extra fine and fine where the attributes for extra fine were a width of $6 \mathrm{~mm}$ and the fine - width between $6 \mathrm{~mm}$ to $8 \mathrm{~mm}$ (Wahome et al., 2011). The fresh weight of each of the grades per plot was determined in grams at every harvest. Unmarketable pods were further graded into thrips damaged and disease damaged fractions and their weight taken. The cumulative total weight was obtained at the end of the three harvests 
Wahome et al. (2013).

\subsection{Data Processing and Analysis}

Data on insect pest population, disease index and yield parameters was subjected to analysis of variance using Genstat $^{\circledR}$, Release15.1. Mean separation of the treatments was accomplished using Fisher's protected Least Significant Difference (Steel et al., 1997).

\section{Results}

Fungal antagonists and crude plant extracts significantly $(\mathrm{P} \leq 0.05)$ reduced the population of whiteflies and thrips (Figure 1; Table 1) compared to the control. Plant extracts however had a significantly $(\mathrm{P} \leq 0.05)$ higher efficacy in reducing the population of whiteflies and thrips compared to the fungal antagonists. Crude plant extracts and the antagonistic fungi compared well with commercial formulations of neem (Achook $0.15 \mathrm{EC}^{\circledR}$ ), Trichoderma $\left(\right.$ Trianum $^{\circledR}$ ) and synthetic pesticide, Confidor ${ }^{\circledR} 70$ WG (Figure 2). The most active plant extracts were garlic and ginger while the most active microbial antagonists were Paecilomyces and Trichoderma spp.. The crude plant extracts and antagonistic fungi reduced the thrips infestation by up to $45 \%$ and $19 \%$ while the antagonistic fungi Trichoderma spp. and Paecilomycesreduced the population of thrips by up to $10.5 \%$ and $20 \%$, respectively.

Antagonistic fungi and plant extracts significantly $(\mathrm{P} \leq 0.05)$ reduced intensity of angular leaf spot, rust and anthracnose (Table 2). The antagonistic fungi were more effective in reducing intensity of the foliar diseases compared to the plant extracts (Figure 3). Trichoderma spp. were the most efficacious, with Trichoderma harzianum and Trichoderma viride spray application showing the least disease intensityfor angular leaf spot, anthracnose and rust. Among the plant extracts, turmeric and garlic were more efficacious compared to the commercial neem Achook ${ }^{\circledR}$. Trichoderma viride reduced disease intensity of angular leaf, rust and anthracnose by up to $37 \%, 51 \%$ and $33 \%$, respectively while T. harzianum reduced disease intensity of angular leaf spot by up to $22 \%$ (Table 2). Turmeric reduced the disease intensity of angular leaf spot and rust by up to $18 \%$ and $33.5 \%$, respectively while ginger reduced disease intensity of anthracnose by up to $15 \%$.

Antagonistic fungi and crude plant extracts significantly $(\mathrm{P} \leq 0.05)$ increased pod yield and reduced pest and disease damaged pods (Table 3). Paecilomyces was the only treatment that resulted in a decrease in total pod yield relative to control. Crude plant extracts and antagonistic fungi increased extra-fine pod yield by up to $26 \%$ and $17 \%$, respectively. Application of the commercial formulation ofneem .(Achook ${ }^{\circledR}$ ) resulted in the largest increase in extra fine and fine pod grades, followed by extracts from ginger and garlic. The yield from plots treated with the three products compared well with yield from plots treated with alternate application of synthetic pesticide and fungicide (Table 3). Antagonistic fungi reduced disease damaged pods more than the plant extracts but comparable to alternate application of Dithane M- $45^{\circledR}$ and Confidor ${ }^{\circledR} 70 \mathrm{WG}$ and Trianum ${ }^{\circledR}$. Garlic extract significantly reduced thrip-damaged pods by $45.5 \%$ followed by Achook $^{\circledR}$ (40.6\%). Trichoderma spp. significantly reduced disease-damaged pods by $48.4 \%$ while Trianum ${ }^{\circledR}$ by $38.9 \%$. Dithane ${ }^{\circledR}$ and Confidor ${ }^{\circledR}$ $(49.1 \%)$ had a slight reduction in disease-damaged pods over Trichoderma spp.

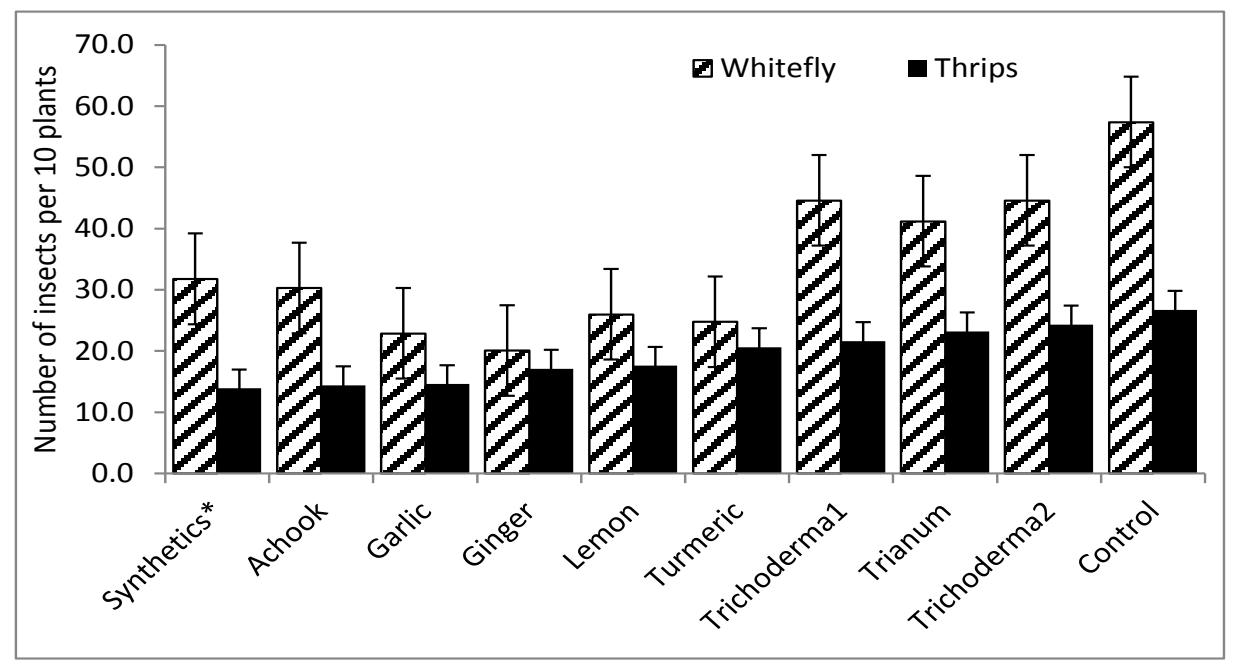

Figure 1. Mean population of white flies and thrips on snap bean crop sprayed with different plant extracts, antagonistic fungi and synthetic pesticides 



Figure 3. Changes in thrips and white fly population over time on snap sprayed with antagonistic fungi and plant extracts as compared to synthetic pesticides and untreated controls

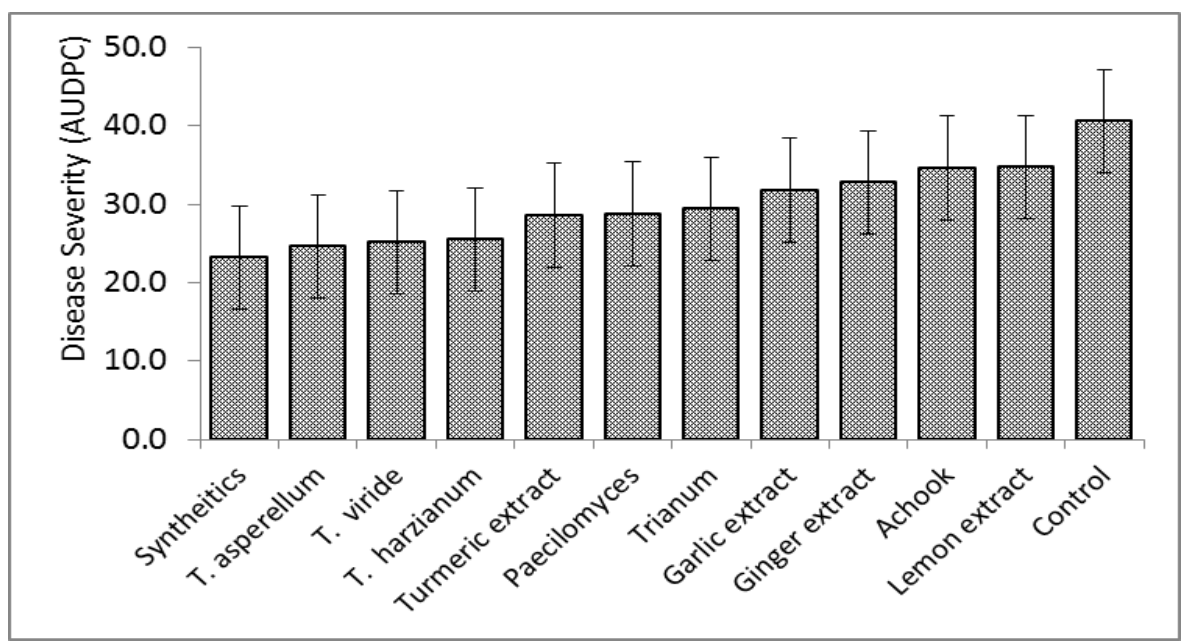

Figure 3. Mean disease severity on snap bean sprayed with antagonistic fungi and plant extracts 
Table 1. Number of whiteflies and thrips on snap beans sprayed with different antagonistic fungi and crude plant extracts during the two cropping season

\begin{tabular}{|c|c|c|c|c|}
\hline \multirow[t]{2}{*}{ Treatment } & \multicolumn{2}{|c|}{ November, 2015-January, 2016} & \multicolumn{2}{|l|}{ March- May, 2016} \\
\hline & Number of Whiteflies & Number of thrips & Number of whiteflies & Number of thrips \\
\hline viride & $44.6 \mathrm{~b}$ & $34.2 \mathrm{bcd}$ & $6.1 \mathrm{bc}$ & $50.3 \mathrm{c}$ \\
\hline T. harzianum & $44.6 \mathrm{~b}$ & $36.4 \mathrm{~b}$ & $5.9 \mathrm{~cd}$ & $53.2 \mathrm{~b}$ \\
\hline T. asperellum & $42.8 \mathrm{~b}$ & $34.9 \mathrm{bc}$ & $5.5 \mathrm{de}$ & $54.2 \mathrm{~b}$ \\
\hline Paecilomyces & $40.8 \mathrm{~b}$ & $37.0 \mathrm{~b}$ & $5.2 \mathrm{e}$ & $43.2 \mathrm{~d}$ \\
\hline Turmeric & 24.8 cde & 30.6 cde & $3.7 \mathrm{fg}$ & $34.3 \mathrm{f}$ \\
\hline Garlic & $22.9 \mathrm{def}$ & $22.4 \mathrm{f}$ & $3.8 \mathrm{fg}$ & $31.6 \mathrm{f}$ \\
\hline Ginger & $20.1 \mathrm{eg}$ & $29.7 \mathrm{de}$ & $3.7 \mathrm{fg}$ & $37.3 \mathrm{e}$ \\
\hline Lemon & 26.0 cde & $28.8 \mathrm{e}$ & $4.3 \mathrm{f}$ & $34.2 \mathrm{f}$ \\
\hline Synthetics & $31.8 \mathrm{~cd}$ & $13.3 \mathrm{~g}$ & $4.3 \mathrm{f}$ & $27.4 \mathrm{~g}$ \\
\hline Trianum ${ }^{\circledR}$ & $41.2 \mathrm{~b}$ & $36.4 \mathrm{~b}$ & $6.6 \mathrm{~b}$ & $52.3 \mathrm{bc}$ \\
\hline Achook ${ }^{\circledR}$ & $30.3 \mathrm{c}$ & $26.6 \mathrm{ef}$ & $3.6 \mathrm{~g}$ & $32.0 \mathrm{f}$ \\
\hline Control & $57.4 \mathrm{a}$ & $44.6 \mathrm{a}$ & $7.7 \mathrm{a}$ & $63.1 \mathrm{a}$ \\
\hline $\operatorname{LSD}(\mathrm{P} \leq 0.05)$ & 7.9 & 4.5 & 0.6 & 2.6 \\
\hline $\mathrm{CV}(\%)$ & 13.1 & 8.5 & 7.0 & 3.6 \\
\hline
\end{tabular}

Means accompanied by different letter(s) in each column are significantly different (Duncan's multiple range test, $\mathrm{P} \leq$ 0.05). Synthetics; Dithane ${ }^{\circledR}+$ Confidor $^{\circledR} ; \mathrm{LSD}=$ Least significant difference; $\mathrm{CV}=$ Coefficient of variation.

Table 2. Percentage disease index on snap beans sprayed with different antagonistic fungi and crude plant extracts for two cropping seasons

\begin{tabular}{lllllll}
\hline Treatment & \multicolumn{3}{l}{ November, 2015-January, 2016 } & \multicolumn{3}{c}{ March-May, 2016 } \\
\cline { 2 - 7 } & ALS & Rust & Anthracnose & ALS & Rust & Anthracnose \\
\hline T. viride & $42.1 \mathrm{def}$ & $12.9 \mathrm{f}$ & $25.1 \mathrm{f}$ & $32.1 \mathrm{fg}$ & $13.2 \mathrm{~h}$ & $24.4 \mathrm{e}$ \\
T. harzianum & $40.7 \mathrm{fg}$ & $14.2 \mathrm{ef}$ & $25.0 \mathrm{f}$ & $33.9 \mathrm{f}$ & $15.5 \mathrm{gh}$ & $25.1 \mathrm{de}$ \\
T. asperellum & $40.9 \mathrm{efg}$ & $14.0 \mathrm{ef}$ & $25.1 \mathrm{f}$ & $37.3 \mathrm{e}$ & $16.2 \mathrm{fgh}$ & $26.2 \mathrm{cde}$ \\
Paecilomyces & $45.4 \mathrm{cde}$ & $15.1 \mathrm{ef}$ & $26.7 \mathrm{def}$ & $41.7 \mathrm{~d}$ & $19.3 \mathrm{def}$ & $27.3 \mathrm{~cd}$ \\
Turmeric & $43.0 \mathrm{def}$ & $16.3 \mathrm{de}$ & $29.7 \mathrm{~b}$ & $42.0 \mathrm{~d}$ & $20.4 \mathrm{cde}$ & $28.4 \mathrm{c}$ \\
Garlic & $43.9 \mathrm{cde}$ & $20.7 \mathrm{~b}$ & $28.2 \mathrm{bcd}$ & $42.9 \mathrm{~cd}$ & $21.7 \mathrm{~cd}$ & $28.2 \mathrm{c}$ \\
Ginger & $47.9 \mathrm{bc}$ & $18.0 \mathrm{~cd}$ & $27.4 \mathrm{cde}$ & $45.0 \mathrm{bc}$ & $22.2 \mathrm{bcd}$ & $34.0 \mathrm{~b}$ \\
Lemon & $51.0 \mathrm{ab}$ & $19.7 \mathrm{bc}$ & $28.2 \mathrm{bcd}$ & $44.4 \mathrm{bc}$ & $23.5 \mathrm{bc}$ & $33.6 \mathrm{~b}$ \\
Synthetics & $37.1 \mathrm{~g}$ & $13.0 \mathrm{f}$ & $25.2 \mathrm{f}$ & $29.9 \mathrm{~g}$ & $15.4 \mathrm{gh}$ & $23.9 \mathrm{e}$ \\
Trianum ${ }^{\circledR}$ & $42.7 \mathrm{def}$ & $16.6 \mathrm{de}$ & $25.7 \mathrm{ef}$ & $37.1 \mathrm{e}$ & $18.2 \mathrm{efg}$ & $26.0 \mathrm{cde}$ \\
Achook & $46.1 \mathrm{~cd}$ & $21.1 \mathrm{~b}$ & $28.9 \mathrm{bc}$ & $45.9 \mathrm{~b}$ & $25.2 \mathrm{ab}$ & $33.2 \mathrm{~b}$ \\
Control & $52.3 \mathrm{a}$ & $24.5 \mathrm{a}$ & $32.2 \mathrm{a}$ & $50.6 \mathrm{a}$ & $26.9 \mathrm{a}$ & $36.6 \mathrm{a}$ \\
Mean & 44.4 & 17.2 & 27.3 & 40.0 & 19.8 & 28.9 \\
LSD (P $\leq 0.05)$ & 4.1 & 2.4 & 1.7 & 2.2 & 3.1 & 2.5 \\
CV $(\%)$ & 5.4 & 8.4 & 3.7 & 3.2 & 9.4 & 5.2 \\
\hline
\end{tabular}

Means accompanied by different letter(s) in each column are significantly different (Duncan's multiple range test, $\mathrm{P} \leq$ 0.05). Synthetics: Dithane ${ }^{\circledR}+$ Confidor $^{\circledR} ; A L S=$ Angular leaf spot; LSD=Least significant difference; $\mathrm{CV}=$ Coefficient of variation. 
Table 3. Marketable pods and non-marketable pods (kg/ha) of snap beans sprayed with different antagonistic fungi and plant extracts for both cropping seasons

\begin{tabular}{|c|c|c|c|c|c|c|c|c|}
\hline \multirow[t]{3}{*}{ Treatment } & \multicolumn{4}{|c|}{ November 2015-January, 2016} & \multicolumn{4}{|c|}{ March-May, 2016} \\
\hline & \multicolumn{2}{|c|}{ marketable pods } & \multicolumn{2}{|c|}{ non-marketable pods } & \multicolumn{2}{|c|}{ marketable pods } & \multicolumn{2}{|c|}{ non-marketable pods } \\
\hline & extra-fine & fine & thrips damage & disease damage & extra-fine & fine & thrips damage & disease damage \\
\hline T. viride & $1523 \mathrm{~cd}$ & $61.1 \mathrm{~b}$ & $1330 a b c$ & $815 \mathrm{~d}$ & $1787 \mathrm{f}$ & 86.7 ef & $581.5 \mathrm{a}$ & $407.4 \mathrm{~d}$ \\
\hline T. harzianum & $1556 \mathrm{~cd}$ & $61.1 \mathrm{~b}$ & $1452 \mathrm{ab}$ & $837 \mathrm{~d}$ & $2120 \mathrm{ef}$ & $100.4 \mathrm{de}$ & $725.9 \mathrm{a}$ & $459.3 \mathrm{bcd}$ \\
\hline T. asperellum & $1541 \mathrm{~cd}$ & $74.1 \mathrm{~b}$ & $1326 \mathrm{abc}$ & $800 \mathrm{~d}$ & $2420 \mathrm{de}$ & $77.2 \mathrm{fg}$ & $663.0 \mathrm{a}$ & $400.0 \mathrm{~d}$ \\
\hline Paecilomyces & $1044 \mathrm{~d}$ & $70.4 \mathrm{~b}$ & $1222 \mathrm{abcd}$ & $867 \mathrm{~d}$ & $1387 \mathrm{~g}$ & $76.2 \mathrm{fg}$ & $611.1 \mathrm{a}$ & $433.3 \mathrm{~cd}$ \\
\hline Turmeric & $1730 \mathrm{bc}$ & $55.5 \mathrm{bc}$ & $1341 \mathrm{abc}$ & $1548 a b$ & $3313 \mathrm{~b}$ & $130.4 \mathrm{ab}$ & $670.4 \mathrm{a}$ & $774.1 \mathrm{ab}$ \\
\hline Garlic & $1559 \mathrm{~cd}$ & $29.6 \mathrm{c}$ & $852 \mathrm{~d}$ & $1267 \mathrm{bc}$ & $2487 \mathrm{de}$ & $114.1 \mathrm{~cd}$ & $548.1 \mathrm{a}$ & $633.3 \mathrm{abcd}$ \\
\hline Ginger & $1400 \mathrm{~cd}$ & $68.5 \mathrm{~b}$ & $1189 \mathrm{abcd}$ & $1674 \mathrm{a}$ & $2587 \mathrm{~d}$ & $105.9 \mathrm{~cd}$ & $711.1 \mathrm{a}$ & $837.0 \mathrm{a}$ \\
\hline Lemon & $1376 \mathrm{~cd}$ & $66.5 \mathrm{bc}$ & $1041 \mathrm{bcd}$ & $1107 \mathrm{~cd}$ & $2253 \mathrm{de}$ & $87.6 \mathrm{ef}$ & $670.4 \mathrm{a}$ & $737.0 \mathrm{ab}$ \\
\hline Synthetics & 2426 a & $59.3 \mathrm{bc}$ & $1059 \mathrm{bcd}$ & $807 \mathrm{~d}$ & $3670 \mathrm{a}$ & $118.2 \mathrm{bc}$ & $663.0 \mathrm{a}$ & $633.3 \mathrm{abcd}$ \\
\hline Trianum $^{\circledR}$ & $1167 \mathrm{~d}$ & $59.2 \mathrm{bc}$ & $1344 \mathrm{abc}$ & $985 \mathrm{~cd}$ & $2203 \mathrm{e}$ & $84.4 \mathrm{efg}$ & $781.5 \mathrm{a}$ & $603.7 \mathrm{abcd}$ \\
\hline Achook $^{\circledR}$ & $2152 \mathrm{ab}$ & $104.0 \mathrm{a}$ & $926 \mathrm{~cd}$ & $1600 \mathrm{ab}$ & 2937 c & $138.5 \mathrm{a}$ & $463.0 \mathrm{a}$ & $666.7 \mathrm{abcd}$ \\
\hline Control & $1207 \mathrm{~cd}$ & $42.6 \mathrm{bc}$ & $1563 \mathrm{a}$ & $1585 \mathrm{ab}$ & $1153 \mathrm{~g}$ & $69.6 \mathrm{~g}$ & $655.6 \mathrm{a}$ & 607.4 abcd \\
\hline Mean & 1556.7 & 62.6 & 1220.4 & 1157.7 & 2360 & 99.1 & 645.4 & 599.4 \\
\hline $\operatorname{LSD}(\mathrm{P} \leq 0.05)$ & 482.3 & 27.6 & 371.9 & 364.5 & 338.5 & 15.2 & 291.9 & 283.9 \\
\hline $\mathrm{CV}(\%)$ & 18.3 & 26.1 & 18.0 & 18.6 & 8.5 & 9.1 & 26.7 & 28.0 \\
\hline
\end{tabular}

Means accompanied by different letter(s) in each column are significantly different (Duncan's multiple range test, $\mathrm{P} \leq 0.05)$. (Synthetics $=$ Dithane $^{\circledR}$ and Confidor ${ }^{\circledR}$.

\section{Discussion}

Application of antagonistic fungi and crude plant extracts reduced the population of whiteflies and thrips on snap bean and their efficacy compared well with commercial formulations of Trichoderma $\left(\right.$ Trianum $^{\circledR}$ ) and synthetic pesticide Confidor ${ }^{\circledR}$. Plant extracts were more efficacious in reducing insect pest populations compared to the antagonistic fungi. All crude plant extracts significantly reduced the population of whiteflies while garlic extract significantly reduced the population of thrips. These findings are in agreement with those of Kiani et al. (2012) who showed that the garlic-onion-pepper extract controlled western flower thrips in the strawberry greenhouse. Also Prakash et al. (2008), Hussein et al. (2014) and Sarwar (2015) reported that garlic and other botanicals exhibited best anti-feedant for vegetable pests while Kalu et al. (2010) reported larvicidal activities of the ethanol extract of garlic bulb against larvae of Culex quinquefasciatus. Leaf extracts of garlic and turmeric have also been reported to be efficacious against larval, pupal and adult of Tribolium castaneum and Trogoderma granarium (Ali et al., 2014; Ahmad et al., 2013; Nwachukwu et al., 2014). The repellent nature of compounds in plant extracts has been attributed to high amounts of allicin in fresh garlic (Nwachukwu et al., 2014; Regnault-Roger, 1997).

Foliar sprays of antagonistic microorganisms and plant extracts reduced the intensity of economically important fungal foliar diseases on snap bean. Trichoderma spp. was the most efficacious. The findings are in line with studies by Elkot and Derbalah (2011), Sawant (2014) and Chhetry and Mangang (2012) who reported that foliar sprays of antagonistic fungi significantly reduced grey mold on cucumber and while foliar application of $T$. harzianum and $T$. viride has been shown to significantly reduce head blight severity on wheat (Sawant, 2014).In this study, the antagonistic Trichoderma spp. had greater efficacy on rust compared to angular leafspot and anthracnose. Similar findings are reported by Akram (2015) who showed that Trichoderma spp. significantly reduced the incidence of Fusarium wilt. The activity of the antagonistic fungi against foliar diseases of snap bean can be attributed to induced systemic resistance, competition, suppression of sporulation and spore germination, suppression of enzyme production by the pathogen,production of antimicrobial toxins and plant growth promoting substances (Sawant, 2014; Živkovićet al., 2010). In mycoparasitism, the antagonist microorganism produces enzymes which hydrolyse the polysaccharides, cellulose, $\beta$-glucans and chitin present in the cell walls of the plant pathogenic fungi (Sawant, 2014). The enzymes include chitinases, N-acetylglucosaminidases, $\beta$-1,3-glucanases, proteases, celluloses, endoglucanases, glucosidases and amylases. 
The observed efficacy of plant extracts in managing foliar diseases on snap bean in the present study is in line findings by Hossain and Hossain (2013) who reported the effectiveness of plant extracts in reducing Tikka disease on groundnuts by up to 63.6\%. Similar findings are reported by Yashoda (2011) and Gurjar et al. (2012) who reported that extracts of garlic, turmeric and ginger had antimicrobial activity against fungi of agricultural significance. Extracts from turmeric and garlic were the most efficacious and this indicates that botanical extracts used in this study have active compounds that inhibit fungal pathogens. Kumar et al. (2012) reported that garlic, ginger and lemon have great potential as antimicrobial compounds against microorganisms and the suppressive nature of garlic bulb crude extract against phyopathogenic fungi has been attributed to the existence of allicin (Wei et al., 2011). The active compounds against pests found in plant extracts include alkaloids, non-proteic amino acids, steroids, phenols, flavonoids, alkaloids, saponins, terpenoids, polyphenolics and polyacetate derivatives, glycosids, glucosinolates, quinones, tanins, salanine, meliantrol, azadiractin, piretrolone, cinerolone and jasmolone that act as contact poisons, stomach poisons, anti-feedants, repellents and confusants, leading to finally death of the insect victims (Javaid and Rehman, 2011; Reddy et al., 2012; Sarwar, 2015). They paralyze nerve activity, respiratory arrest, and act on the central and peripheral nervous system leading to convulsions and finally death of the pest (Sarwar, 2015). The antimicrobial activity of garlic and turmeric are attributed to allicin and curcumin, respectively (Gurjar et al., 2012). Garlic extract contains olerisine substance, a volatile oil made up of allyl propyl disulphide that has anti-feedant effect (Hussein et al., 2014). Extracts of neem are reported to stimulate the plant natural defence response and cause changes in plant metabolism leading to changes in level of enzymes and content of phenolic compounds that have adverse effects on the pathogen (Hussein et al., 2014).

Application of antagonistic fungi and extracts increased yield of marketable pods and reduced the yield of pest and disease damaged pods. The findings of this study are consistent with those by Soliman et al. (2015) and Sawant (2014) who reported that application of formulations based on fungal antagonist can promote plant growth and crop precocity, increase in legume production and reduce chemical treatment. However, Amin et al. (2014) reported that application of $T$. viride and T. harzianum had no effect on yield in common bean. The observed increase in pod yield can be attributed to the reduction in pest and disease damage and also to plant growth promoting substances present in produced by the antagonists and also found in the antifungal plant extracts (Sawant, 2014; Živkovićet al., 2010). This study indicated that antagonistic fungi and plant extracts are effective in managing pests and diseases in snap bean, resulting in increase in yields.

The findings of this study showed that antagonistic fungi and plant extracts are effective in management of insect pests and diseases in snap beans in fields. Crude plant extracts were effective in reducing population of whiteflies while Trichoderma spp. were effective in lowering development and spread of rust, anthracnose and angular leaf spot. The effectiveness of plant extracts and fungal antagonists against pests and diseases translated to increased yield of quality pods. Therefore, plant-based biopesticides and antagonistic fungi can provide alternatives to synthetic pesticides in the management of pests and diseases in snap beans, thereby reducing harmful chemical residues and loss of produce at the export market. This would minimize produce interceptions and improve the competitiveness of snap bean pods at niche markets. More studies should be conducted to determine active compounds of antagonistic fungi and botanical extracts used in this study. This will be useful in the formulation and consequent commercialization of these biopesticides. An ideal biological control agent should be economical to produce, possess good storage stability, have high residual activity, easy to handle, provide consistent and effective control against the target pests (Gašić and Tanović, 2013). Addition of carriers and adjuvants to the microbial antagonist help to protect the active microorganism from environmental conditions, allows the survival of the active biological agent and improves storage stability. Microbial pesticides have advantages over synthetic pesticides because they are biodegradable, they do not leave residues in the soil, are less harmful to humans or animals, and more accessible in less developed countries (Prakash et al., 2008; Leahy, 2014; Sarwar, 2015). Plant extracts as biochemical pesticides are degradable, non-persistent in the environment, lethal to target pest and are broader spectrum (Leahy, 2014) hence their effect on beneficial organisms should be investigated.

\section{Acknowledgement}

The Regional Universities Forum for Capacity Building in Agriculture (RUFORUM) is gratefully acknowledged for funding this study under Grant ID RU 2014 GRG-096.

\section{References}

Ahmad, F., Sagheer, F., Hammad, A., Rahman, S. M. M., \& Hasan, M. (2013). Insecticidal activity of some plant extracts against Trogodermagranarium(E.). A Scientific Journal of Krishi Foundation, 11(1), 103-111.

Ahmed, F. F., Mansour, A. E. M., Montasser, M. A. A., Merwad, M. A., \& Mostafa, E. A. M. (2013). Response 
of Valencia orange trees to foliar application of roselle, turmeric and seaweed extracts. Journal of Applied Sciences Research, 9(1), 960-964.

Ahmed, M. A., Rao, A. S., Ahemad, S. R., \& Ibrahim, M. (2012). Phytochemical studies and antioxidant activity of Melia azedarach leaves by DPPH scavenging assay. International Journal of Pharmacitical Application, 3, 271-276.

Akrami, M. (2015). Effects of Trichoderma spp. in bio-controlling Fusarium solani and F. oxysporum of cucumber (Cucumissativus). Journal of Applied Environmental and Biological Sciences, 4(3), 241-245.

Aktar, M. W., Sengupta, D., \& Chowdhury, A. (2009).Impact of pesticide use in Indian agriculture - Their benefits and hazards. Interdisciplinary Toxicology, 2(1), 1-12. https://doi.org/10.2478/v10102-009-0001-7

Ali, S., Sagheer, M., Hassan, M., Abbas, M., Hafeez, F., Muhammad, F., Dilbar, H., Saleem, M., \& Ghaffar, A. (2014). Insecticidal activity of turmeric (Curcuma longa) and garlic (Allium sativum) extracts against red flour beetle, Triboliumcastaneum: A safe alternative to insecticides in stored commodities. Journal of Entomology and Zoology Studies, 2(3), 201-205.

Amin, M., Fitsum, S., Selvaraj, T., \& Mulugeta, N. (2014). Field Management of anthracnose (Colletotrichumlindemuthianum) in common bean through fungicides and bioagents. Advances Crop Science and Technology, 2, 124. https://doi.org/10.4172/2329-8863.1000124

Archana, M. R., \& Ramaswamy, K. (2012). Interactive effect of entomopathogenic fungi Paecilomyces fumosoroseus with few organophosphate and pyrethroid pesticides: an in vitro study. Indian Journal of Fundamental and Applied Life, 2(2), 10 -17.

Chandler, D., Bailey, A. S., Tatchell, G. M., Davidson, G., Greaves, J., \& Grant, W. P. (2011). The development, regulation and use of biopesticides for integrated pest management. Philosophical Transactions of the Royal Society B, 366, 1987-1998. https://doi.org/10.1098/rstb.2010.0390

Chhetry, G. K. N., \& Mangang, H. C. (2012). Evaluation of ecofriendly management practices of French bean rust (Uromycesappendiculatus) in organic farming system. International Journal of Advancements in Research and Technology, 1(4), 1-7.

Elkot, G. A. E., \& Derbalah, A. S. H. (2011).Use of cultural filtrates of certain microbial isolates for powdery mildew control in squash. Journal of Plant Protection Research, 51(3), 252-260.

https://doi.org/10.2478/v10045-011-0042-8

European Commission (2012). Amending Annex I to Regulation (EC) No 669/2009 implementing Regulation (EC) No 882/2004 of the European Parliament and of the Council as regards the increased level of official controls on imports of certain feed and food of non-animal origin. Official Journal of the European Union. L. 350/44. 20/12/2012.

Gašić, S., \& Tanović, B. (2013). Biopesticide Formulations, Possibility of Application and Future Trends. Pestic. Phytomed. (Belgrade), 28(2), 97-102. https://doi.org/10.2298/PIF1302097G

Gupta, S., \& Dikshit, A. K. (2010).Biopesticides: An ecofriendly approach for pest control. Journal of Biopesticides, 3(1), 186-188.

Gurjar, M. S., Ali, S., Akhtar, M., \& Singh, K. S. (2012). Efficacy of plant extracts in plant disease management. Agricultural Sciences, 3, 425-433. https://doi.org/10.4236/as.2012.33050

Horticultural Crops Development Authority (HCDA), (2011). Horticultural Crops Development Authority, Ministry of Agriculture, Kenya. Horticulture Report, 2011.

Hossain, M. H., \& Hossain, I. (2013). Screening of different plant extracts against leaf spot (CercosporaarachidicolaandCercosporidiumpersonatum) of groundnut (ArachishypogaeaL.). Bangladesh Journal of Agricultural Research, 38(3), 491-503. https://doi.org/10.3329/bjar.v38i3.16976

Hussein, N., M.., Hussein, M. I., Hak S. H. G., \& Hammad, M. A. (2014).Effect of two plant extracts and four aromatic oils on TutaAbsoluta population and productivity of tomato cultivar gold stone. Nature and Science, 12(7), 108-118.

Infonet-biovision (2015). Tomatoes, http://www.infonet-biovision.org/default/ct/80/pests.Accessed 25/01/2015

Islam, R., Jeong, Y. T., Lee, Y. S., \& Song, C. H. (2012). Isolation and identification of antifungal compounds from Bacillus subtilis C9 inhibiting the growth of plant pathogenic fungi. Mycobiology, 40(1), 59-66. https://doi.org/10.5941/MYCO.2012.40.1.059 
Javaid, A., \& Rehman, A. H. (2011). Antifungal activity of leaf extracts of some medicinal trees against Macrophominaphaseolina. Journal of Medicinal Plants Research, 5(13), 2868-2872.

Kalu, I. G., Ofoegbu, U., Eroegbusi, J., Nwachukwu, C. U., \& Ibeh, B. (2010).Larvicidal activities of ethanol extract of Allium sativum(garlic bulb) against the filarial vector, Culexquinquefasciatus. Journal of Medicinal Plants Research, 4(6), 496-498.

Kamanu, J. K., Chemining'wa, G. N., Nderitu, J. H., \& Ambuko J. (2012). Growth, yield and quality response of snap bean (Phaseolus vulgaris L.) plants to different inorganic fertilizers applications in Central Kenya. Journal of Applied Biosciences, 55, 3944-3952.

Kenya Plant Health Inspectorate Services (KEPHIS) (2012). The introduction of increased checks on Kenyan exported beans and peas in pods by the European Union. http://www.kephis.org/99-regulation669amended.html.

KEPHIS. (2012). The introduction of increased checks on Kenyan exported beans and peas in pods by the European Union. Presented at a meeting with stakeholders exporting beans and peas. Nairobi, Kenya.

Kiani, L., Yazdanian, M., Tafaghodinia, B., \& Sarayloo, M. H. (2012). Control of western flower thrips, Frankliniellaoccidentalis (Pergande) (Thysanoptera: Thripidae), by plant extracts on strawberry in greenhouse conditions. Munis Entomology and Zoology, 7(2), 857-866.

Killani, A. S., Abaidoo, R. S., \& Akintokun, A. K. (2011). Rice husk extract is potentially effective as a phytopesticide against root-/soil-borne fungal pathogens of cowpea. Nature and Science, 9(3), 72-79.

Kimani, V. (2014). Biopesticides development, use and regulation in Kenya.Regional experts' workshop on development, regulation and use of biopesticide in East Africa. Slide share. Accessed on 21/12/2014.

Koul, O. (2011). Microbial biopesticides: Opportunities and challenges. Biopesticide Research Centre, 30-Parkash, India. CAB Reviews: Perspectives in Agriculture, Veterinary Science, Nutrition and Natural Resources, 6(56), 1-26.

Krishan, J. (2014). Global trends in the development and use of biopesticides. Regional experts workshop on development, regulation and use of bio-pesticides in East Africa in Nairobi on 22-23 May 2014. http://www.bioinnovate-africa.org/regional-experts-workshop-on-development-regulation-and-use-of-bio-pestici des-in-east-africa/.

Kumar, A., Prakash, A., \& Johri, B. N. (2011). Bacillus as PGPR in Crop Ecosystem: In. Maheshwari, D. K (Ed.). Bacteria in Agrobiology: Crop Ecosystems. Springer-Verlag Berlin Heidelberg.

https://doi.org/10.1007/978-3-642-18357-7_2

Leahy, J., Mendelsohn, M., Kough, J., Jones, R., \& Berckes, N. (2014). Biopesticide oversight and registration at the U.S. Environmental Protection Agency. American Chemical Society.

https://doi.org/10.1021/bk-2014-1172.ch001

McKinney, (1923). A new system of grading plant disease. Journal of Agricultural Research, 26, 195-218.

Navaneetha, T., Prasad, R. D., Venkateswara, Rao, L. (2015). Liquid formulation of Trichoderma species for management of graymold in castor (RicinuscommunisL.) and Alternariaster leaf blight in sunflower (Helianthus annuusL.). Journal of Biofertilizer and Biopesticides, 6(1), 1-11.

Nderitu J, Mwangi, F., Nyamasyo, G., \& Kasina, M. (2009). Evaluation of cropping systems as a strategy for managing snap bean flower thrips in Kenya. International Journal of Sustainable Crop Production, 4(6), 22 -25.

Nderitu, J. H., Kasina, M. J., Nyamasyo, G. N., Waturu, C. N., \& Aura, J. (2008). Management of thrips (Thysanoptera: Thripidae) on French beans (Fabaceae) in Kenya: Economics of insecticide applications. Journal of Entomology, 5, 148-155. https://doi.org/10.3923/je.2008.148.155

Ndung'u, A. (2013). Kenya spills the beans. Horticultural News, pp. 36-37.

Nega, A. (2014). Review on concepts in biological control of plant pathogens. Journal of Biology, Agriculture and Healthcare, 4(27), 33-54.

Nwachukwu, I. D., \& Asawalam, E. F. (2014).Evaluation of freshly prepared juice from garlic (Allium sativum L.) as a biopesticide against the maize weevil, Sitophilus zeamais (Motsch.) (Coleoptera: Curculionidae). Journal of Plant Protection Research, 54(2), 132-138. https://doi.org/10.2478/jppr-2014-0021

Obagwa, J., \& Korsten, L. (2002). Control of citrus and green and blue molds with garlic extracts. Plant Pathology, 109, 221-225. https://doi.org/10.1023/A:1022839921289

Odero, D. O., Mburu, J., Ackello-Ogutu, C., \& Nderitu, J. H. (2013). Value chain analysis of smallholder snap 
bean production in Kirinyaga County, Kenya, African Association of Agricultural Economists (AAAE) fourth international conference, September 22-25.

Ogala, B. O. (2013). Management of thrips in French bean by use of integrated pesticide application regimes in Embu East and Mwea East Districts. M.Sc.Thesis, University of Nairobi, Kenya.

Ouma, B., Muthomi, J., Nderitu, J., \& Toroitich, F. (2014). Management of thrips in French beans by integrating biological and synthetic pesticides in conventional spray regimes. Journal of Renewable Agriculture, 2(2), 27-37. https://doi.org/10.12966/jra.06.02.2014

Poorniammal, R., \& Sarathambal, C. (2009). Comparative performance of plant extracts, biocontrol agents and fungicides on the diseases of sunflower. Indian Journal of Weed Science, 41(3\&4), 207-209.

Prakash, A., Rao, J., \& Nandagopal, V. (2008). Future of botanical pesticides in rice, wheat, pulses and vegetables pest management. Journal of Biopesticides, 1(2), 154-169.

Quarles, W. (2013). New biopesticides for IPM and organic production. The IPM Practitioner, 33(7/8), 1-9.

Quarles, W., (2013). New Biopesticides for IPM and Organic Production. The IPM Practitioner, 33(7/8).

Reddy, M. N., Mishra, J. G., \& Lathiya, D. G. (2012). In vitro antifungal activity of aqueous extracts of some medicinal plants against Aspergillus niger. International Journal of Chemical and Biomolecular Science, 3(1), $5-8$.

Regnault-Roger, C. (1997). The potential of botanical essential oils for insect pest control. Integrated Pest Management Review, 2, 25-34. https://doi.org/10.1023/A:1018472227889

Sarwar, M. (2015). The killer chemicals for control of agriculture insect pests: The botanical insecticides. International Journal of Chemical and Biomolecular Science, 1(3), 123-128.

Sawant, I. S. (2014). Trichoderma-foliar pathogen interactions. The Open Mycology Journal, 8(1), 58-70. https://doi.org/10.2174/1874437001408010058

Shahid, M. A, Balal, R. M., Pervez, M. A., Abbas, T., Aqeel, M. A., Javaid, M. M., \& Garcia-Sanchez, F. (2015). Foliar spray of phyto-extracts supplemented with silicon: an efficacious strategy to alleviate the salinity-induced deleterious effects in pea (PisumsativumL.). Turkish Journal of Botany, 39, 408-419.

https://doi.org/10.3906/bot-1406-84

Shaner, G., \& Finney, R. A. (1977). The effect of nitrogen fertilization on the expression of slow-mildewing resistance in Knox wheat. Phytopathology, 67, 1051-1056. https://doi.org/10.1094/Phyto-67-1051

Singh, A. S., Panja, B., \& Shah, J. (2014). Evaluation of suitable organic substrates based Trichoderma harzianum formulation for managing Rhizoctonia solani causing collar rot disease of cowpea. International Journal of Current Microbiology Applied Science, 3(8), 127-134. https://doi.org/10.1007/s00284-014-0566-z

Soliman, H. M, El-Metwally, M. A, Elkanky, M. T., \& Badawi, W. E. (2015). Alternatives to chemical control of grey mold disease on cucumber caused by Botrytis cinerea Pers. Asian Journal of Plant Pathology, 9(1), 1-15. https://doi.org/10.3923/ajppaj.2015.1.15

Srinivasan, R. (2012). Integrating biopesticides in pest management strategies for tropical vegetable production. Journal of Biopesticides, 5, 36-45.

Stavely, J. R. (1985). The Modified Cobb Scale for estimating bean rust intensity. Ann. Rep. Bean Improv. Coop, 28, 31-32.

Steel, R. G. D, Torrie, J. H., \& Dickey, D. A. (1997). Principles and Procedures of Statistics: A Biometrical Approach. 3rd Ed. McGraw-Hill, New York.

Upadhyay, J. P., \& Mukhopadhyay, A. N. (1986). Biological control of SclerotiumrolfsiibyTrichoderma harzianumin Sugar beet. Tropical Pest Management, 32, 215-20. https://doi.org/10.1080/09670878609371066

USAID-KHCP (2015). Global competitiveness study: Benchmarking Kenya's horticulture sector for enhanced export competitiveness. Fintrac Inc.

https://www.fintrac.com/sites/default/files/USAID-KHCP\%20Global\%20Competitiveness\%20Study_0.pdf.

Wafula, G. O. (2014). Potential of potassium salts and integrated pest management strategies in management of snap bean pests. M.Sc. Thesis, University of Nairobi, Kenya.

Wahome, S. W., Kimani P. M., Muthomi, J. W., \& Narla, R. D. (2013). Quality and yield of snap bean lines locally developed in Kenya. International Journal of Agronomy and Agricultural Research, 3(7), 1-10. 
Wahome, S. W., Kimani, P. M., Muthomi, J. W., Narla, R. D., \& Buruchara, R. (2011). Multiple disease resistance in snap bean genotypes in Kenya Journal of Food Agriculture, Nutrition and Development, 19(4), 289-302.

Waiganjo, M. M., Waturu, C. N., Mureithi, J. M., Muriuki, J., Kamau, J., \& Munene, R. (2011). Use of entomopathogenic fungi and neem bio-pesticides for Brassica pests control and conservation of their natural enemies. East AfrAgric Forestry J, 77, 545-549.

Wei, T., Cheng, Z., Khan, M. A., Qing, A., \& Ling, H. (2011). The inhibitive effects of garlic bulb crude extract on Fulviafulva of tomato. Pakistan. Journal of Botany, 43(5), 2575-2580.

Wheeler, B. E. J. (1969). An introduction of plant disease. John Wiley and Sons Limited, London: 301.

Yashoda, P., Hegde, R., Prashanthi, S. K., Nargund, V. B., \& Venugopal, C. K. (2011). Antifungal effect of botanicals against Cercosporabeticola, the incitant of leaf spot of palak. Karnataka Journal of Agricultural Science, 24(4), 575-576.

Živković, S., Stojanović, S., Ivanović1, Ž. Gavrilović1, V., Popović, T., \& Balaž, J. (2010). Screening of antagonistic activity of microorganisms against Colletotrichum acutatum and Colletotrichum gloeosporioides. Archives of Biological Sciences, 62(3), 611-623. https://doi.org/10.2298/ABS1003611Z

\section{Copyrights}

Copyright for this article is retained by the author(s), with first publication rights granted to the journal.

This is an open-access article distributed under the terms and conditions of the Creative Commons Attribution license (http://creativecommons.org/licenses/by/3.0/). 